\title{
Nadia Boulanger: "In the midst of the stars"
}

\author{
Dominique Marie Baeta \\ College of Arts, University of Florida
}

Faculty mentor: Brenda Smith, School of Music

\begin{abstract}
Nadia Boulanger was the French performer/teacher who changed the landscape of American music. Under the mentorship of her father, Ernest Boulanger, and the tutelage of musical genius, Gabriel Faure at the Paris Conservatory, Nadia Boulanger had an excellent education and earned high honors as a student of organ and composition. However, early in her life Boulanger decided to turn her full focus to teaching. Among Boulanger's most outstanding American composition students are Aaron Copland, Walter Piston, Roy Harris, Philip Glass, and Virgil Thomson. Student testimonials and class notebooks shed light on her teaching techniques. She taught with a combination of rigor and passion, successfully mentoring a generation of aspiring composers and performers. Her profound imprint on American music is recognizable in the fact that almost all American composers of note in the 20th century studied with Boulanger either in Paris or during her residency in Boston. This research investigated how Nadia Boulanger taught American composers, why she was successful, and how her early education affected her future as a composition teacher. By examining materials from her schooling and work as a teacher (compositions, student testimonials, and class notebooks), it was possible to trace the concepts of the "grande ligne", independent voice, humble master, and freedom within structure throughout her life.

Keywords: music, teaching, grande ligne
\end{abstract}

\section{Introduction}

Nadia Boulanger was the French performer/teacher who changed the landscape of American music. Among her most outstanding American students are prize-winning composers: Aaron Copland, Walter Piston, Virgil Thomson, Roy Harris and Philip Glass. She was a famous teacher of Americans, but taught several international students, including Sir Lennox Berkeley.

Boulanger's influence stretched beyond teaching in a traditional setting, allowing her to serve as an educator to a wider public. She edited the music of Igor Stravinsky, championed the works of Claudio Monteverdi, J. S. Bach, and Gabriel Fauré, and served as the first female conductor of several world class orchestras (Brooks 36). Despite her many successes, her greatest influence on American music came through teaching composition. Nadia Boulanger was so influential in the United States that Virgil Thomson once said, "legend credits every United States town with two things: a five and dime and a Boulanger student" (qtd. in Campbell 5). This research investigates 
how Nadia Boulanger taught American composers, why she was successful, and how her early education affected her future as a composition teacher. By examining materials from her schooling and work as a teacher (compositions, student testimonials, and class notebooks), it was possible to trace the concepts of the "grande ligne", independent voice, humble master, and freedom within structure throughout her life.

\section{Early Education}

Nadia Boulanger was born in 1887 to Raissa Michetsky and Ernest Boulanger. Both parents came from musical backgrounds. Ernest worked as a singing teacher at the Paris Conservatory, and won first prize in composition in the coveted Prix de Rome competition. Nadia's mother, Raissa, studied voice with Ernest Boulanger (Campbell 16). Nadia enrolled at the Paris Conservatory at the age of 9 and began studying with Gabriel Fauré at the age of 14 (Campbell 21; Nectoux "Gabriel Fauré: a musical life" 264). At the Conservatory, she won first prizes in harmony, organ, piano accompaniment, and fugue (Campbell 23). Following in her father's footsteps, Nadia competed in the Prix de Rome competition in 1908, winning second place (Campbell 24). She caused a sensation when she composed the mandatory fugue for a string quarter instead of voices. After heated debate, she was allowed to continue in the competition, but any chance of winning first place was gone (Spycket 22). Already, she was making her mark on the musical landscape around her. Although she experienced early success as a composer, Nadia preferred teaching, and turned her full focus to it early in her career (Campbell 24).

\section{The "grande ligne"}

Nadia Boulanger's classes with Gabriel Fauré were highly influential in her composing and teaching. She began to form the concept of providing structure to music, or music having a "grande ligne", in her years at the Conservatory with Fauré. Here she described the "grande ligne" idea: "Music is made up of two essential elements (line and rhythm) which are completed by decorative elements (harmony and orchestration)--the goal is attained if the coordinated use of these elements corresponds to the emotion from which is born the idea which they seek to develop" (qtd. in Walters 88). Boulanger believed that all music, regardless of genre or instrumentation, needed a "grande ligne". Aaron Copland described how the presence of this "grande ligne" affected the listener and provided another definition of the term. He said,

"Boulanger had one all-embracing principle, namely, the desirability of aiming first and foremost 
at the creation of what she called 'la grande ligne' in music. Much was included in that phrase: the sense of forward motion, of flow and continuity in the musical discourse; the feeling for inevitability, for entity" (Copland and Perlis 67). A musical comparison illustrates how Nadia Boulanger and her teacher, Gabriel Fauré, share this compositional characteristic. Fauré composed "Clair de Lune" in 1887 (Nectoux "Fauré, Gabriel"). "Clair de Lune", or moonlight in French, paints a beautiful picture of a magical night, where the moonlight mingles with all life on Earth. Fauré expressed the feeling of beautiful mystery in the harmonies in the piano prelude. "Elegie", or eulogy, written by Boulanger in 1906, resembles "Clair de Lune" in its forward motion and use of harmony to convey mystery (Potter). Despite the mysterious feelings associated with both songs, they have the structure and forward motion necessary to the presence of a "grande ligne". The structure is present in the constant use of eighth notes in the piano line that pulls the listener along. The harmonic content of each song, though unusual, creates chord progressions that lead the listener through the overarching stories.

independent voice. The "grande ligne" provides structure to music, but this structure is only useful if it helps the composer compose freely. Fauré encouraged each individual student and assisted them on their journey to find their own voice. Nadia Boulanger described how it made his students feel, "We for our part were keenly aware of this desire of his to understand us and to offer the verbal guidance that would help us most easily to find our own way" (qtd. in Nectoux "Gabriel Fauré: a musical life" 264). Encouraging individuality became a staple of Boulanger's teaching.

Considering another musical comparison, this encouragement of individuality in voice is found when examining "Fleur Jeteé" by Gabriel Fauré and "Le Couteau" by Nadia Boulanger. The "grand ligne" is present in both songs, but these songs are stylistically different than previous works by their respective composers. "Fleur Jeteé", by Fauré, compares love to a flower that has been plucked and tossed aside. To convey the angriness of the flower, Fauré provided driving eighth notes in the piano part. Unlike the beautiful and starry "Clair de Lune", "Fleur Jeteé" is biting, sounding unlike most of Fauré's other music. Boulanger's "Le Couteau", or "the knife," is similar to "Fleur Jeteé" in its sentiment. The poem again describes unrequited love, this time comparing the love to a knife stuck in the lover's heart. Directly under the title, Boulanger added the descriptor "Populaire," or "popular". In doing this, she indicated to sing in the style of popular music of the time, something she does not try to adopt in her other music. 
humble master and presence. At the Paris Conservatory, Gabriel Fauré's students included Maurice Ravel, Charles Koechlin, Jean Roger-Ducasse, Florent Schmitt, and of course, Nadia Boulanger (Gordon 97). Another concept Boulanger adopted from Fauré was how to be a humble master. Despite his success as a composer, Fauré was a humble master as a composition professor. Boulanger took note of his presence in the classroom. His influence "was invisible and indefinable, coming not from any substance in the material he taught but simply from the man he was. He inspired in us a kind of veneration. His utter simplicity shielded us from all false pretensions" (qtd. in Nectoux “Gabriel Fauré: a musical life” 264).

\section{How She Taught}

Though Nadia Boulanger was a traditionalist in many aspects of her life, as evidenced by her hesitation to accept serialism as a serious musical style, the way she taught was often far from traditional. Boulanger would teach all day, and late into the night (Campbell 38). When asked about retirement she responded, "Retirement? I don't know what that is. One works or one cannot work...that would be death" (qtd. in Hughes). She did not write a book or discuss pedagogy often, choosing to spend her time teaching students instead of talking about teaching. Boulanger taught at traditional institutions and was a teacher to a much wider audience through her travels, giving lectures and performances. More specifically, it was possible to piece together how she taught using student testimonials and materials from her courses.

\section{Institutions and travels.}

When teaching through an institution, Nadia Boulanger taught private lessons and group lecture courses. She often taught harmony courses, including at the Longy School in Boston, and Fontainebleau, the American music school in France opened by the famous conductor, Walter Damrosch. Boulanger's contract with the Longy School in Boston, where she taught from 19401943, outlined her responsibilities to include "8 teaching hours a day from Monday to Thursday" including "courses, lessons, seminars" ("Longy School of Music"). Despite contractual constraints, Boulanger taught on her own schedule. For example, in this contract, she requested to have Fridays free so that she could travel ("Longy School of Music"). She often spent longer than the allotted time for lessons and took on extra students when she sensed potential.

Nadia Boulanger made multiple trips to the United States and around Europe, performing and teaching at premier colleges and venues. Throughout the United States, she gave lectures and performances at Harvard University, University of Chicago, Princeton, Radcliffe, and Wellesley 
("Nadia Boulanger- Schedule"). She performed with The Boston Symphony Orchestra in 1925 and became the first female conductor of the BSO in 1938, the New York Philharmonic in 1938, and the Royal Symphony Orchestra in 1936 (Brooks 36). In regard to her conducting debuts, Boulanger's response reflected how she felt about all the glass ceilings she was shattering, "I've been a woman for a little over 50 years and have gotten over my initial astonishment. As for conducting, that's a job. I don't think sex plays much part" (qtd. in "Woman Who Refused"). These travels allowed her to champion the music of Gabriel Fauré, Igor Stravinsky, and her sister, Lili Boulanger. Nadia Boulanger cemented her place in history as a musician and teacher of note by recognizing, and sharing with others, what made these composers notable.

notebooks and testimonials. The ideas of structure and the "grand ligne" shed light on specific practices and exercises used by Nadia Boulanger. Notebooks from her courses by students Robert Levin and R. E. Mueller, located in the Nadia Boulanger Collection at the Isham Memorial Library at Harvard University, demonstrated how she used fugue and harmony exercises to teach students (Boulanger and Levin; Boulanger and Mueller). She would have students' study and copy examples by master composers to learn about form and harmony (Boulanger and Levin; Boulanger and Mueller). Examining materials from her Longy course revealed that a notebook was made for the class, with preset instructions and exercises. The notebook diligently worked through the material, starting with simple major and minor triads, and moving to realizing dense chord progressions (Boulanger). These notebooks also revealed how she would edit students' works, with fragments of compositions by the students having feedback written in red ink (Boulanger and Levin). None of these practices were ground breaking, but in Lennox Berkeley's words, "Nadia Boulanger teaches that the composer must first be a good workman, who knows his job, and that then only is he free to write what he likes, and to realize what ideas he has; that it does not matter how much drudgery you go through to gain that freedom, for a man must lose his life in order to find it, and in music he must lose his originality and personality in order to find them." (Berkeley) Freedom was realized in her ability to help students find their individual voices, an ability that made her uniquely successful as a teacher.

\section{Why She Was Successful}

Regarding the teaching of composition, there is debate as to whether the skill can be acquired or comes from natural ability. The esteemed composer and professor at the University of Florida, 
Dr. Paul Basler, said, “I really don't believe that anyone can teach composition...but what you can do is you can guide and you can make suggestions" (Basler). Certainly, Nadia Boulanger guided and made suggestions, but many of her students still find it difficult to describe her teaching and aura, and why she was successful in helping them. Gayle Murchison put it best when he described Boulanger's teaching as "musical midwifery" (37). She expected a high level of musicianship from her students, and described this relationship between structure and freedom, "Without order there can be no inner satisfaction. Without inner satisfaction, there can be no freedom. Without freedom there can be no joy" (qtd. in Campbell 96).

\section{Freedom}

Nadia Boulanger's success as a teacher was not only due to rigor, but due to what she could inspire and pull out of the student. Boulanger had an extraordinary ability to help a student find their voice. This "voice" is a creative one, not a singing voice. Twyla Tharp, the famous choreographer and muse of dance, called the idea of a creative voice the "creative DNA", and believed "we all have strands of creative code hard-wired into our imaginations" (37). Boulanger was able to work with a student and recognize the strands of this "creative DNA" (Tharp 37). Copland described this process, "Well, she knew how to look at a page of music, or even a half a page of music dispassionately. And to judge it in terms of what that particular student sitting next to her was able to accomplish. She could sort of guess for you, not one way the piece might be developed, but three different ways or four different ways without telling you what to do" (Copland and Calland). Nadia Boulanger would judge a piece of music based on the composer's abilities, not her own preferences. Then, she would guide the student in the right direction without telling them what to do. In this way, Boulanger influenced and assisted her students to become better versions of themselves, not just exact copies of something that already existed.

A musical example of this journey from student to composer, structure to freedom, can be seen from Aaron Copland's “As it Fell Upon a Day" to his "Nature, the Gentlest Mother." Copland composed "As it Fell Upon a Day" in 1923 as an assignment for Boulanger (Copland and Perlis 90). Here he described the assignment, "I had been playing around with some ideas for the flute and clarinet assignment when I came upon a poem by the seventeenth-century English poet Richard Barnefield. 'As It Fell Upon a Day' had the simplicity and tenderness that moved me to attempt to evoke that poignant expression musically..." (Copland and Perlis 90). In the opening of "As it Fell Upon a Day", Copland evokes the sounds of a forest with bird calls and animals 
scurrying around in the flute and clarinet parts. It opens with bird calls in the piano part, setting up the image of a forest before the text is sung. This was a snapshot of what was to come in the pinnacle of his works in the art song genre: "Twelve Poems of Emily Dickinson", composed from 1949 to 1950 ("Copland, Aaron"). In both pieces, Copland used the accompaniment to the voice as the setting for the text. Putting the scene in the accompaniment was common in Nadia Boulanger's music as well. Both songs have a "grande ligne", with "As it Fell Upon a Day" sounding like a precursor to "Nature, the Gentlest Mother". The ability to tell a story through music exhibited in Aaron Copland's “As it Fell Upon a Day" is expanded upon in "Nature, the Gentlest Mother".

Boulanger's excellent pedigree allowed her to teach composers with many different, independent voices. In Copland's words, "Mademoiselle knew everything there was to know about music, she knew the oldest and the latest music, pre-Bach and post-Stravinsky and knew it cold" (qtd. in Hume). She taught the likes of Copland and Ives, but her influence even extended into the world of pop music (Campbell 51). A BBC reporter described her impact, "Quincy Jones, producer of choice for everyone from Frank Sinatra to Aretha Franklin to Michael Jackson...told me in all earnestness that he owed everything he was as a musician to his early instruction, in 1950s Paris, under Nadia Boulanger... Q told me that Boulanger had a singular way of encouraging and eliciting each student's own voice - even if they were not yet aware of what that voice might be." (Burton-Hill).

aura. Nadia Boulanger adopted the aura of a humble master with her individual students, and especially in her larger classes and lectures. When delivering her lectures at Rice University in 1925, entitled "Lectures on Modern Music", Boulanger spoke in English, even after being given the opportunity to deliver them in French (Francis 367). She used humor to joke about her accent and put the audience at ease (Francis 367-68). The lectures received glowing reviews in local newspapers, and Nadia Boulanger was commended for making a complex subject easy to understand. (Francis 371). Students felt comfortable exploring their talents without hesitation thanks to this humble attitude and ability to instill confidence in others.

Copland did not originally go to Paris to study with Boulanger. In an NPR interview from 1980, Copland explained his move, "The new music seemed to be coming from Paris and Stravinsky was living in Paris, that was a big draw. So I headed for Paris" (Copland and Calland). In fact, he had not heard about Boulanger until after he arrived at Fontainebleau. 
During the summer of 1921, Copland did not study with Boulanger, but soon learned about her presence in the classroom through other students. Eventually, he attended one of her lectures, stating, "There was something about the warmth with which she was talking about this dull subject of harmony. All of a sudden, harmony seemed like the whole, the very basis of all the art of music, you know" (Copland and Calland). Like most of Boulanger's future American students, Copland immediately felt her presence in the classroom and the passion Boulanger instilled in the subject she taught. He started studying with her soon after (Copland and Calland). Copland was the first in a long list of American Boulanger students who would go on to shape the future of American music.

\section{Conclusion}

Nadia Boulanger's musical education, specifically at the Paris Conservatory with Gabriel Fauré, allowed her to develop as a musician and as a teacher. During this time, she developed her concept of the "grande ligne", her own independent voice as a composer, and learned the meaning of being a humble master in the classroom. When teaching her own students, she reinforced the three concepts mentioned above, as well as adding her own concept: the idea of having freedom within structure. The compositions, student testimonials, and class notebooks serve as evidence for how she inspired students with her passion for music, while challenging them to become technically proficient musicians.

Despite her commitment to the music of the past, Boulanger made her biggest impact on the music of the future. She lived long enough to see her students not only accomplish great compositional feats, but to also inspire other composers to do the same. Aaron Copland is often called the father of American music because of his influence on those who came after him. Through Aaron Copland and her other American students, Nadia Boulanger's legacy stretches far beyond the borders of any country or lifetime.

When asked about music, this was how she responded, "Nothing is better than music; when it takes us out of time, it has done more for us than we have the right to hope for: it has broadened the limits of our sorrowful life, it has lit up the sweetness of our hours of happiness by effacing the pettiness's that diminish us, bringing us back pure and new to what was, what will be, what music has created for us" (qtd. in Campbell 63). 


\section{Acknowledgements}

Thank you to my research mentor, Dr. Brenda Smith, for her continued support and assistance with this project. Thank you to Dr. Paul Basler for sharing his knowledge about teaching composition. Thank you to Dr. Roy Rudolph for his assistance in securing the materials from the Longy School of Music, and to Dr. Alan Asher for securing resources at the University of Florida.

\section{References}

Basler, Paul. Interview by Dominique Baeta. "Nadia Boulanger." 12:40pm, 5 Oct. 2017.

Berkeley, Lennox. "Nadia Boulanger As Teacher.” The Monthly Musical Record, 1 Jan. 1931, www.musicweb-international.com/classrev/2008/June08/Boulanger_Berkeley.htm.

Boulanger, Nadia. "Harmony Course.” 1938-45. Longy School of Music, Boston.

Boulanger, Nadia and Levin, Robert. "Music Notebook." Box 19, 1963-64. Scores by American Composers 1920-1977 (Bulk). Nadia Boulanger Collection in Isham Memorial Library in Loeb Music Library at Harvard University.

Boulanger, Nadia and Mueller, R. E. "Music Notebook.” Box 22, 1963-64. Scores by American Composers 1920-1977 (Bulk). Nadia Boulanger Collection in Isham Memorial Library in Loeb Music Library at Harvard University, Boston.

Burton-Hill, Clemency. "The Greatest Music Teacher Who Ever Lived.” BBC, 19 Apr. 2017.

Campbell, Don G. Master Teacher: Nadia Boulanger. The Pastoral Press, 1984, Washington D.C.

Copland, Aaron. Interview by Fred Calland. "Paris, Prokofiev, and Nadia Boulanger.” NPR, Nov. 1980.

Copland, Aaron and Perlis, Vivian. Copland: 1900 through 1942. St. Martin's/Marek, 1984, New York.

Francis, Kimberly. "Everything Had to Change': Nadia Boulanger's Translation of Modernism in the Rice Lecture Series, 1925.” Journal of the Society for American Music, vol. 7, no. 4, 2013, pp. 363-381., doi:10.1017/S1752196313000357.

Gordon, Tom. Regarding Fauré. Gordon and Breach Publishers, 1999, Amsterdam.

Hughes, Allen. "Nadia Boulanger, Teacher of Top Composers, Dies." The New York Times, 23 Oct. 1979.

Hume, Paul. "The Lessons of Nadia Boulanger.” The Washington Post, 11 Sept. 1977.

Longy School of Music. "Nadia Boulanger Contract". Longy School of Music, May 1941, Boston.

Murchison, Gayle. The American Stravinsky. The University of Michigan Press, 2012, Ann Arbor.

“Nadia Boulanger- Schedule of public engagements, January - May, 1939.” Longy School of Music, 1939, Boston.

Nectoux, Jean-Michel. "Fauré, Gabriel." Grove Music Online, 2001. Oxford University Press.

Nectoux, Jean-Michel. Gabriel Fauré: a musical life. Translated by Roger Nichols, Cambridge University Press, 1991, Cambridge.

Pollack, Howard. "Copland, Aaron." Grove Music Online, 16 Oct. 2013. Oxford University Press. 
Pollack, Howard. "Piston, Walter." Grove Music Online, 2001. Oxford University Press.

Potter, Caroline. "Boulanger, (Juliette) Nadia." Grove Music Online, 2001. Oxford University Press.

Spycket, Jérôme. Nadia Boulanger. Translated by M. M. Shriver, Pendragon Press, 1992, New York.

Stehman, Dan, and Beth E. Levy. "Harris, Roy." Grove Music Online, 31 Jan. 2014. Oxford University Press.

Strickland, Edward. "Glass, Philip." Grove Music Online, 2001. Oxford University Press.

Tommasini, Anthony, and Richard Jackson. "Thomson, Virgil." Grove Music Online, 10 Jul. 2012. Oxford University Press.

Walters, Teresa. Nadia Boulanger, Musician and Teacher: Her Life, Concepts, And Influences. (volumes I And Ii), Peabody Institute of the Johns Hopkins University, Ann Arbor, 1981, ProQuest, https://login.lp.hscl.ufl.edu/login?URL=http://search.proquest.com.lp.hscl.ufl.edu/accountid=109 20?url=https://search-proquest-com.lp.hscl.ufl.edu/docview/303150582?accountid=10920.

"Woman Who Refused to Teach George Gershwin First of Sex to Conduct Boston Philharmonic." New York Sun, 15 Feb. 1938. 